\title{
Education as a Value in the Pregraduate Studies of Education in Ukraine
}

\author{
Pavlína Kobzová \\ Palacký University Olomouc, Czech Republic \\ Jitka Plischke \\ Palacký University Olomouc, Czech Republic \\ Markéta Šemberová \\ Palacký University Olomouc, Czech Republic
}

\begin{abstract}
The paper focuses on the description of the value of education in pregraduate preparation of students of teaching disciplines in Ukraine. The aim of the text is to specify the course of preparation for the profession of teacher in the context of values from the perspective of students of selected pedagogical faculties in Ukraine. The issue of values in the pregraduate preparation of Ukrainian students of teaching is a partial part of the authors' long-term interest in the issue of education and the values of Ukrainian pupils in schools in the Czech Republic. The research is carried out using a mixed QVAN - qval design. A Likert-type scale questionnaire supplemented with semi-closed and open items was chosen as the research tool. The data are analyzed with the predominance of a simple statistical analysis with additional analysis using grounded theory.
\end{abstract}

Keywords: value, education, pregraduate preparation, students of teaching, Ukraine

\section{Introduction}

Pregraduate teacher education, wherever in the world it is implemented, should be based on a broad and thorough general education. However, we also see the importance of the role of the teacher in understanding the goals, meaning and values of education and in their further mediation in the educational process. All the more so, values are necessary equipment for the future teacher, who participates in the education of pupils and the formation of their profile and value orientation. In our research, we ask ourselves what values do students encounter in pregraduate study? Are there values present at all? How do students perceive the issue of values within education? At the same time, what values do they think should not be missing in the education of pupils in the school environment? We tried to answer these questions in the presented paper. 


\section{Literature Review}

Educational experts, teachers and the public wonder what is the main goal of teacher education? What professional knowledge and skills, values and attitudes should a teacher graduate be equipped to become a competent teacher in the conditions of modern education? Today's society places high demands on teachers.

According to Mikešová (2005), the uniqueness of the profession of teacher lies in the fact that it is based on relationships, love for children, which teachers take care of from an educational point of view. The profession of teacher is a mission therefore it contains a significant personal contribution of teaching adepts. Much more than any other profession, it requires a high degree of self-control, responsibility and patience. One of the goals of teachers' educational activities is to pass on to students the basic values widely accepted and recognized not only in the Czech, resp. European society, but in today's society, built on a Christian basis in the past, which clearly includes the values of responsibility, diligence, patience, decency, honesty, justice, truthfulness and integrity.

The same values are mentioned in Ukrainian curricular documents, such as the Law of Ukraine on Education, which declares values influencing the all-round development of a person's personality, his right to education and the importance of universal education for society. An integral part of teaching in Ukrainian schools is the incorporation of the values of patriotism, respect for the homeland and the emphasis on spiritual and moral aspects in education (Kobzová, 2018).

Preparation for the profession of teacher is a crucial point in the future professional career of a teacher. Although there are currently tendencies that diminish the importance of the teacher and his perception as a pupil's guide to the educational process, we believe that the role of the teacher remains crucial and irreplaceable for the pupil's development.

According to Šimoník (2004, pp. 13-14), pregraduate preparation can be defined as the unity of theory and practice. However, pregraduate preparation cannot produce a ready-made teacher. It is necessary to complete the pedagogical mastery through years of systematic work on oneself, constant self-reflection and further education. Students can achieve real pedagogical perfection by not only concentrating all their skills on passing on knowledge, but by teaching their pupils to think independently and to think critically. They will be teachers who encourage themselves and their pupils to improve.

One of the key tasks in pregraduate preparation is to accompany future teachers to take professional responsibility for the full development of the pupil's personality and, of course, for their own education and professional growth. It is not enough to be professionally trained in the modern concept of education, but the emphasis should be on internal motivation, willingness to engage in the educational process and the development of attitudes and values in future teachers (Spilková, 2007, pp. 12-13). Emphasis in pregraduate studies should therefore also be placed on improving and increasing the level of the ethical aspect of the teacher's personality. It also seems desirable to include subjects dealing with ethical and value dilemmas and problems in the current school. However, this requires certain ideals and personality patterns that the present time is painfully lacking.

This condition was described by Blížkovský et al. (2000), who already twenty years ago carried out a detailed analysis of the pedagogical preparation of students for the future 
profession, which proved to be insufficient. Due to previous social conditions, the following has increased in teacher education:

1) scientism, which manifested itself in the prevailing scientific approach to education,

2) value antinomism, which may be characterized by absolute non-commitment and resignation to the ability to shape a new system of values and goals in education.

We believe that a similar situation prevailed and still survives also in the Ukrainian education system.

The quality of the pupils' educational process and everything that takes place in teaching therefore depends not only on the thorough preparation of the teacher, but is deeply connected with the teacher's personalities, with his self-understanding. The teacher is a very important variable in the teaching process and in the relationship with students and parents. Lukášová $(2015$, p. 26) considers that the most important thing is "how the teacher internally understands his profession, how he understands it and how he evaluates it and on the basis of what values he approaches the profession." This dimension of teaching is also perceived by Spilková (2015) who states that the teacher's task is not only to develop the cognitive level of pupils, but the teacher should also be able to pass on the love of knowledge, learning and cognition. However, it is born only through the teacher's relationship with students and his "commitment to the profession" (2015, p. 165).

We will also think about the process of education from the point of view of teacher virtues. Behind the moral qualities of a teacher, Helus (2004, pp. 222-223) perceives the goal of pedagogical effort, which is effort to "be a reliable support for pupils in their personal development". According to the author, the favorable development of the teacher's character is related to several pedagogical virtues, including pedagogical love, pedagogical mind, pedagogical courage and pedagogical credibility.

Although pedagogical preparation within Europe, including Ukraine, has many features in common, especially when it comes to the compulsory combination of general, special, psychopedagogical education, practical training (Kocan, 2013), each country has its own specifics within its own educational system, linguistic and cultural diversity, and educational traditions in general. With regard to the value issues in pregraduate study in Ukraine, continuous education is currently becoming one of the main principles of pedagogical efforts, which is becoming an integral part of human existence in general (Kocan, 2013).

Fundamental principle of modern education to redirect pregraduate study to the personality of a student teacher. The approach is known as a personality-oriented model of preparation of future teachers and involves a deep psychologization of teacher training, the development of pedagogical thinking and the formation of skills such as setting educational goals, analyzing pedagogical situations, making decisions in the best interests of the child and relying on strength rather than weakness. Volynecka (2013) states the priority of personality-oriented learning are both the character of the teacher and his preparation. An important starting point for the preparation of future teachers is the art of respecting the development of the student as a person who is constantly changing with age, has its own characteristics, specifics of development.

The values in the pregraduate preparation of future teachers, which are increasingly focused on, are communication culture and competencies, empathy, tolerance, in other words -"the 
search for ways of mutual understanding between teachers and students is the key to positive change in a period of social anomie and the devaluation of a number of moral principlesdecency, kindness, devotion, mutual help"(Kocan, 2013, p. 189). The relationship between teacher and student should be filled with respect and empathy. And this is a difficult task in a situation of polyethnicity, social differentiation and different intellectual abilities and talents of each individual pupil. The belief that none of the students, regardless of background, ability or performance, can be limited in their personal development begins in the period of pregraduate education of students as future teachers.

\section{Methodology}

The research was carried out by means of an electronic questionnaire survey among respondents - students of teaching of pedagogical faculties in Ukraine in the cities of IvanoFrankivsk, Brody and Ternopyl. The administration of the online questionnaires took place during December 2019 to May 2020. A total of 120 completed questionnaires were obtained with all the data necessary for the analysis. The research involved Ukrainian pregraduate students of the 2 nd - 7 th year of study with specialization mainly for teaching primary and lower secondary level of education. The most frequent length of studies was stated by the participants at:

- 4 years (56\% of participants)

- 3 years (29\% of participants)

The sample of respondents consisted of $87.5 \%$ women (total number 105) and 12.5\% men (total number 15) aged 18-22 years.

As a research tool, a 5-degree Likert-type questionnaire was chosen, supplemented by semiclosed and open items, which were analyzed within the grounded theory. The questionnaire consisted of a total of 20 items. For the scale items, the respondents recorded on the scale the degree of their agreement or disagreement with the given statement, while 3 types of scales were used in the questionnaire:

1) 1 least important, 2 unimportant, 3 intermediate, 4 very important, 5 most important,

2) 1 strongly disagree, 2 rather disagree, 3 don't know, 4 rather agree, 5 strongly agree,

3) 1 least, 2 less, 3 medium, 4 more, 5 most,

\section{Analysis}

The research tool was divided into two basic parts:

\section{Introductory questions}

The first part of the questionnaire consisted of introductory questions focused on demographic data including gender, age of respondents, length of study which were already mentioned above. In this part, the specialization of study participants, their motivation to study and the pattern in education were ascertained (see Graphs below).

Graph 1. Representation of studied specializations 


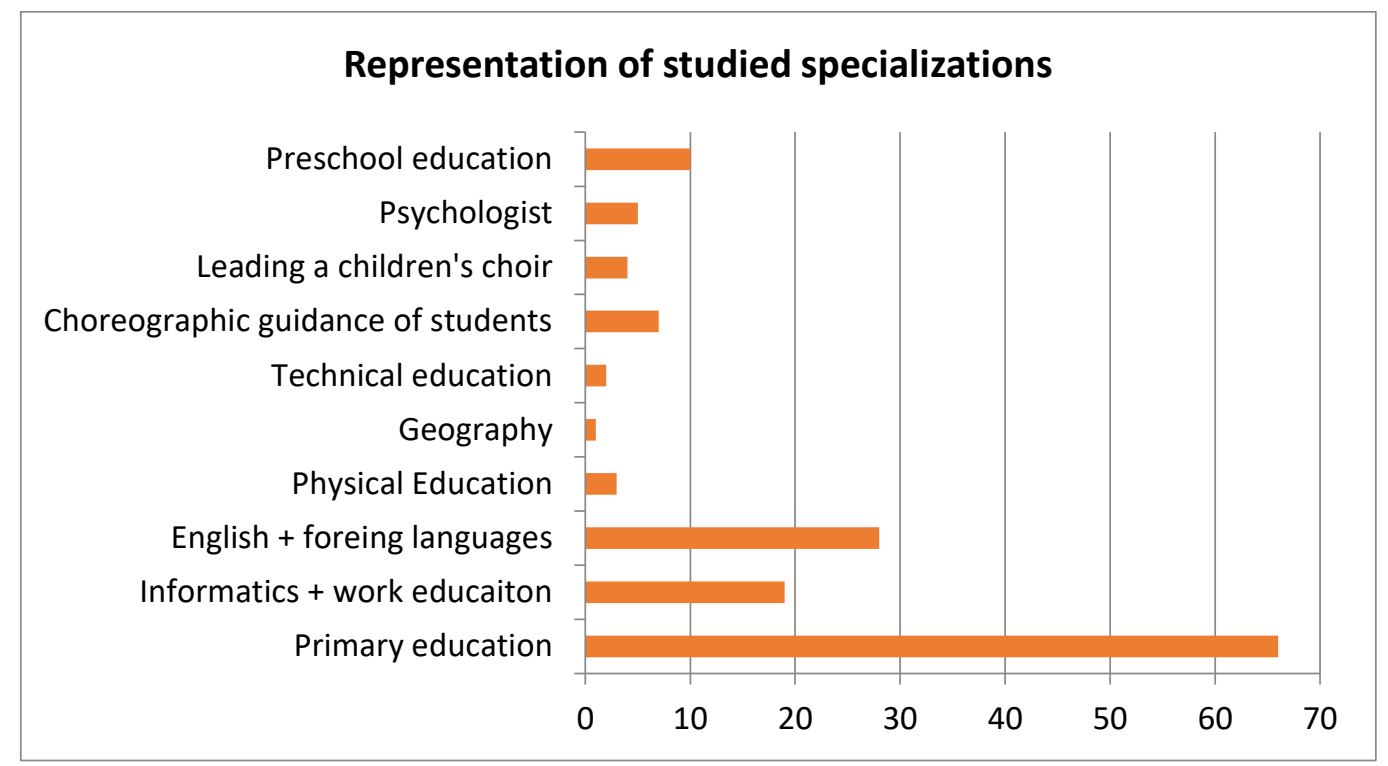

Among the most numerous specializations in the study among the respondents were clearly teachers of primary education, ie 1 st - 4 th class (66 respondents). The second most frequently studied specialization was English and other foreign languages (28). In third place in the number of selected answers is informatics and work education (19).

Graph 2. Motivation of students to study profession of teaching

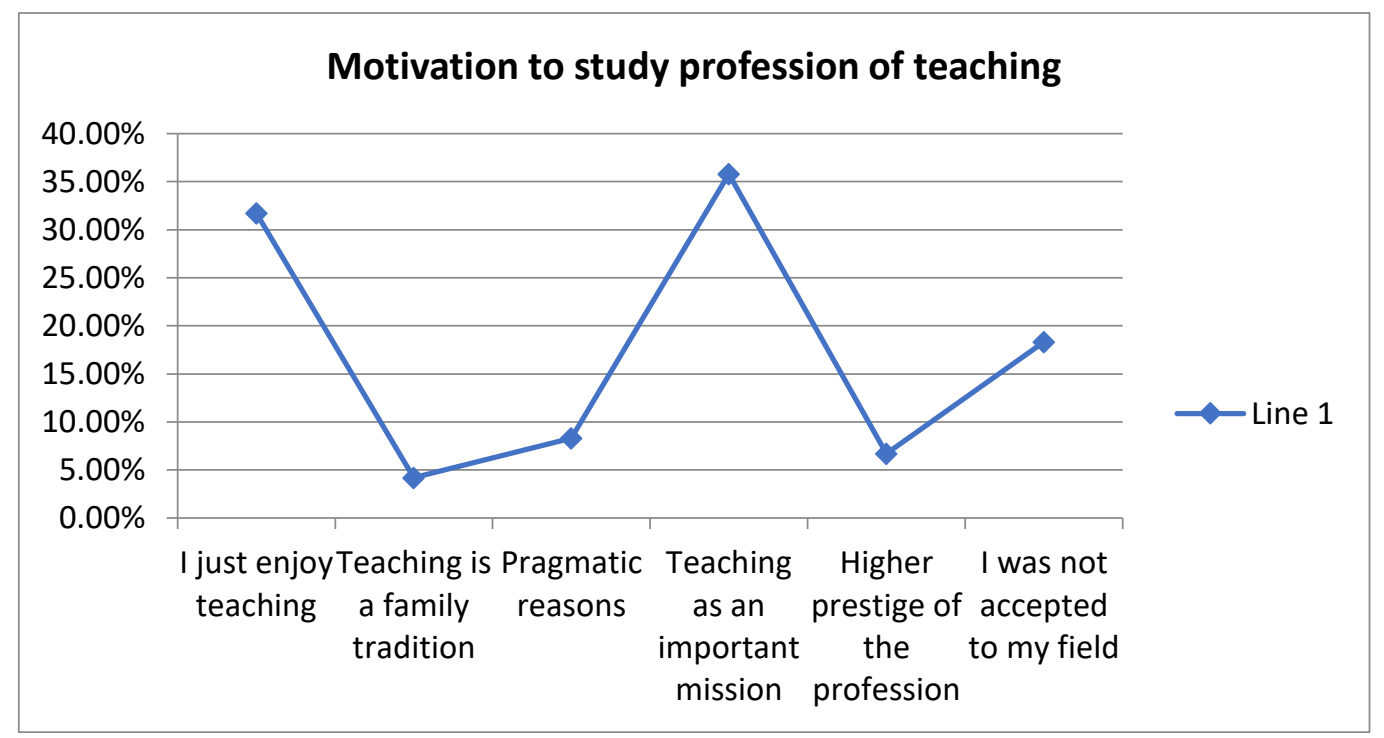

The attached graph shows that the highest number of respondents (35.8\%) perceive the teaching profession as key as their motivation was "teaching as an important mission". The contrast of this motivation with the low percentage of motivation of "higher prestige of the profession" is interesting. Thus, most students do not consider the profession to be prestigious 
and important before society, and at the same time they understand it as an important social mission. The second highest representation in the number of elections gained the motivation "I enjoy teaching" (31.7\%), which can be described as a motivation to study for self-realization.

Graph 3. Role models of students in education

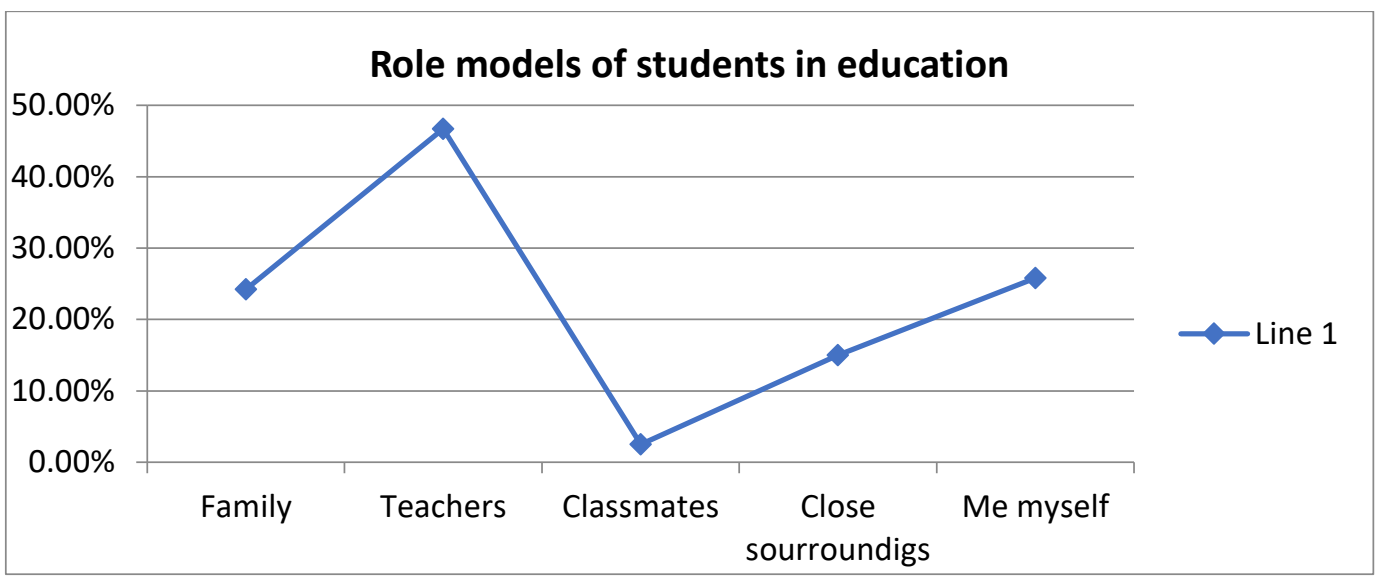

Looking at the graphical representation of the data, we find that for the most part the examined students were role models in education, primarily teachers (46.7\%). Here we see how much the example of a teacher and the way he/she performs profession affect students. The second most common example in the field of study are respondents for themselves $(25.8 \%)$ and in close proximity to them is their family's inspiration for education $(24.2 \%)$.

II. Statistical analysis supplemented by qualitative analysis

In the second part of the questionnaire, the attitudes and values of students scale are identified. For the purpose of quantitative evaluation of the research tool, the frequency of choice of respondents' answers for individual statements was determined and subsequently these frequencies were converted into numerical form. Another necessary step was the assignment of numerical values to individual scale items and the calculation of the coefficient (Gavora, 2010). The individual frequencies were then multiplied by these coefficients. The resulting sum of all multiples was divided by the number of respondents, and the resulting value showed the average distribution of answers (Chráska, 2016). A low overall score identified an average overall negative attitude toward the statement, and a high overall score represented a positive attitude.

Tab. 1. Total coefficient of choice of answers

\begin{tabular}{|l|l|}
\hline $\begin{array}{l}\text { 1. Which pedagogical disciplines are most important in the study (according to } \\
\text { the hourly subsidy) }\end{array}$ \\
\hline General education subjects & 3,12 \\
\hline General didactics & 3,16 \\
\hline Field didactics & 3,05 \\
\hline Pedagogical-psychological disciplines & 3,18 \\
\hline Professional training (in the chosen field) & 3,2 \\
\hline Pedagogical practice & 3,18 \\
\hline
\end{tabular}




\begin{tabular}{|l|l|}
\hline 2. Which pedagogical disciplines formed your personality the most? & \\
\hline General education subjects & 3,12 \\
\hline General didactics & 2,94 \\
\hline Field didactics & 3,02 \\
\hline Pedagogical-psychological disciplines & 3,04 \\
\hline Professional training (in the chosen field) & 3,29 \\
\hline Pedagogical practice & 3,16 \\
\hline
\end{tabular}

In the first item respondents rated Pedagogical-Psychological disciplines (3.18) as moderately to very important (on a scale of 1 to 5), which provide students with a basis for reflection on educational processes at school. They make it possible to acquire knowledge about the entrusted pupils, skills and attitudes necessary for the appropriate direction of the actors of education, to get to know the world of the pupil better. The respondents also attached the same importance to pedagogical practices (3.18), which mediate students' contact with the educational reality and where the knowledge and skills of all the above-mentioned components of teacher preparation are integrated.

The coefficients of the second item indicate that respondents consider the most formative subject to be training in the chosen field (3.29) and pedagogical practice (3.16), both coefficients again lying between medium to very important values. It turns out that especially professionally and practically oriented subjects of teacher training have a more intense influence on the formation of students' personal qualities than other subjects. The statement is also proved by the analysis of open answers, in which the respondents agree that the training in the chosen approval allows to focus on the core of specialization, ie the education of younger pupils and everything related to it. Pedagogical practice will allow respondents to critically evaluate their impact, test their knowledge in practice and find out where their weaknesses are, what to work on. In addition, school practice encourages the development of a sense of responsibility, patience and the ability to accept children as they are.

\begin{tabular}{|l|l|}
\hline 3. What is the focus of the study of teaching at your faculty? & \\
\hline At us, student and for better professional readiness & 3,59 \\
\hline On the study program of teaching (on subjects) and its improvement & 3,33 \\
\hline On interpersonal relationships, collegiality and the overall atmosphere & 3,21 \\
\hline
\end{tabular}

In this item, it was found out in which direction the study of future teachers is oriented. According to the results, we see that students perceive the greatest focus of their study program on them, as on students and on their professional development and training. The calculated coefficient of 3.59 is the highest in comparison with the other two and approaches the overall rating of 4 , which states the value as very important. An interesting finding, however, is that the statement regarding interpersonal relationships and the overall atmosphere in the school was less chosen by the respondents. However, this is not a big difference.

\begin{tabular}{|l|c|}
\hline $\begin{array}{l}\text { 4. In your opinion, in what way does the teacher contribute the most to the quality of } \\
\text { pupils' education? }\end{array}$ & \\
\hline $\begin{array}{l}\text { A clear vision of the educational process and specifically formulated goals of } \\
\text { teaching, with which he/she acquaints students. }\end{array}$ & 3,45 \\
\hline With his personality, ie natural authority and the right educational effect on the pupils. & 3,79 \\
\hline
\end{tabular}




\begin{tabular}{l|c|}
\hline $\begin{array}{l}\text { Perfect knowledge of the subject matter and its interpretation, which will inspire } \\
\text { pupils for the subject. }\end{array}$ & 3,71 \\
\hline $\begin{array}{l}\text { Teacher-pupil interaction, ie by providing space for pupils to actively participate in } \\
\text { teaching. }\end{array}$ & 3,8 \\
\hline
\end{tabular}

In the given item, the students assessed the way the teacher influenced the quality of education on a scale from 1 to 5 with an evaluation, which is again close to point 4 . It can be stated that students consider a very important way of the teacher and how to behave in relation to pupils with emphasis on the support of pupils' activity by the teacher in teaching (3.8). Respondents also assessed the position of the teacher and his personality by almost the same coefficient (3.79), whom, if he/she is a role model and has natural authority, they perceive as a fundamental factor in the educational process. However, they also perceive as an integral part the excellent knowledge of the subject matter, including didactic and professional knowledge (3.71), without which the performance of the profession of teacher cannot be imagined.

\begin{tabular}{|l|l|}
\hline $\begin{array}{l}\text { 5. What values (attitudes) did you acquire in connection with the profession of } \\
\text { teacher within the study? }\end{array}$ & \\
\hline Love to the profession of teacher, the concept of the profession as a mission, & 3,75 \\
\hline Subject matter orientation - to transfer knowledge to pupils, & 3,56 \\
\hline Focus on the pupil, on his individual development and perception of his needs, & 3,74 \\
\hline Emphasis on good organization of teaching, mastery of discipline in the classroom, & 3,63 \\
\hline $\begin{array}{l}\text { Ability to communicate and cooperate with each other in the teaching community and } \\
\text { with pupils' parents, }\end{array}$ & 3,80 \\
\hline Emphasis on prestige and the status of teachers in society. & 3,38 \\
\hline
\end{tabular}

Given the values and attitudes that respondents have gained so far in the study of teaching, the highest number of choices gained the ability to communicate and cooperate with teachers' colleagues (3.80), which means that it influences pedagogical practice, which students evaluated at most in 1st and 2nd items. However, the respondents gave an important place to the fact that during their studies they gained a stronger relationship with the profession of teaching, which they perceive as a mission and which represents a very important value for them (3.75). The focus on pupils, the development of their personality, the ability to perceive their needs and requirements gained a similar importance (3.74). Of all the least, future teachers value the prestige of the profession of teaching in front of society, which is largely related to the low salary of teachers in Ukraine and the overall unfavorable economic situation in the country.

\begin{tabular}{|l|l|}
\hline 6. Which values do you prefer and which are the least important for you? & \\
\hline Professional success, prestige, good salary, material gain, & 3,55 \\
\hline Education, self-development, professional success and work that makes sense, & 3,87 \\
\hline Family, children, love, life partner, & 3,79 \\
\hline Health, world peace, healthy environment, ecology, & 3,85 \\
\hline $\begin{array}{l}\text { Freedom, democracy, the idea of private enterprise, participation in the economic life } \\
\text { of society, }\end{array}$ & 3,44 \\
\hline $\begin{array}{l}\text { Altruism, helping people, solidarity, participation in political events through a public } \\
\text { benefit function, }\end{array}$ & 3,45 \\
\hline $\begin{array}{l}\text { Friendship, love, hobbies, interests, social relationships that do not require } \\
\text { responsibility. }\end{array}$ & 3,53 \\
\hline
\end{tabular}


The question on the preference of values was used to find out which of them future teachers prefer and which they neglect. However, the achieved coefficients of individual statements show very balanced scores in all areas of values and range from medium to more preferred values (3-4). Respondents appreciate the most the values of education, personal growth and the profession in which they can be realized, which at the same time goes beyond their own satisfaction and benefit (3.87). Second in line is health and peace in the world, the choice can be partly attributed to the current security situation in Ukraine. The statement family, children, love received a surprisingly lower rating, despite the fact that this value is the highest among Ukrainians according to the author's long-term study of the Ukrainian national minority in the Czech Republic.

\begin{tabular}{|l|l|}
\hline $\begin{array}{l}\text { 7. What (national and cultural) values are, in your opinion, passed on to current } \\
\text { primary school pupils in Ukraine? }\end{array}$ & \\
\hline Emphasis on professional success, prestige, good salary in the future profession, & 3,32 \\
\hline Education, self-development, creativity, & 3,6 \\
\hline Family, children, love, & 3,49 \\
\hline Health, world peace, healthy environment, ecology, & 3,8 \\
\hline The idea of freedom, independence and democracy, & 3,52 \\
\hline Altruism, helping people, solidarity, & 3,55 \\
\hline $\begin{array}{l}\text { Friendship, love, hobbies, interests, social relationships that do not require } \\
\text { responsibility. }\end{array}$ & 3,6 \\
\hline
\end{tabular}

With slightly modified statements, we found out what values, in the opinion of the respondents, are passed on and formed by contemporary Ukrainian education. The students attributed the highest level of consent to the health, world peace and interest in a healthy environment (3.8), to which they also gave a higher value in their personal value orientations. Another important value formed in the Ukrainian pupils generation is friendship, interests, love and relationships (3.6) which, however, are not based on responsibility for others. The students also evaluated the area of education, creativity and emphasis on pupils' personal development with the same coefficient. Based on a qualitative analysis, it should be added that many values promoted in education, such as patriotism, friendship, tradition or competence in the field of the environment, some respondents consider as purely formally formed. These values and attitudes are presented only externally, they have no deeper anchorage and they lack a moral basis.

\begin{tabular}{|l|l|}
\hline $\begin{array}{l}\text { 8. Which of the following values would you like to form at the pupils as a future } \\
\text { teacher? }\end{array}$ & \\
\hline Emphasis on professional success, prestige, good salary in the future profession, & 3,55 \\
\hline Education, self-development, creativity, & 4,14 \\
\hline Family, children, love, & 3,71 \\
\hline Health, world peace, healthy environment, ecology, & 4 \\
\hline The idea of freedom, independence and democracy, & 3,64 \\
\hline Altruism, helping people, solidarity, & 3,89 \\
\hline $\begin{array}{l}\text { Friendship, love, hobbies, interests, social relationships that do not require } \\
\text { responsibility. }\end{array}$ & 3,79 \\
\hline
\end{tabular}


We were interested in which of the mentioned areas of values teacher students would like to form with their pupils and to what extent their answers coincide with their preferred values (item 6). In this case, the response rate coefficient ranged from 3.55 to 4.14. The highest frequency of elections was again recorded in the value of education, self-development and creativity (4.14), which future teachers would like to form the most among pupils. Their choice here also agrees with their choice of personal value No. 1. A possible explanation for why students value education and self-development the highest may be the desire to pass on education to pupils, thanks to which they can get later on the opportunity to study abroad. The belief that in a Western democratic society, education and work effort will be better appreciated than in their own country may also play a role here. However, a completely opposite reason cannot be ruled out, namely to have an educated population that is better able to lead a country that is plagued by economic instability and war. Last but not least, the respondents would like to pass on to the pupils the previously mentioned value of health care (4) and the pattern of altruistic behavior and the ability to help those in need (3.89). These values are perceived by students as key to the future development of Ukrainian society.

\begin{tabular}{|l|l|}
\hline $\begin{array}{l}\text { 9. What values and attitudes are needed to educate the current generation of } \\
\text { Ukrainian pupils with regard to their future personal, professional and social } \\
\text { application? }\end{array}$ & \\
\hline to self-realization, self-awareness and the ability to assert oneself in life, & 3,94 \\
\hline to national awareness and loyalty to the Ukrainian nation, & 3,63 \\
\hline to broader knowledge, lifelong learning, & 3,85 \\
\hline to the love of democracy, freedom and independence, & 3,68 \\
\hline to justice, truthfulness, morality and honesty, & 4,2 \\
\hline to faith, to respect for God and for man. & 4,4 \\
\hline
\end{tabular}

The results of the frequency of choice of answers clearly show the need to take root in faith and respect for God, which is then automatically be reflected in greater respect for man $(4,4)$. In the case of Ukraine as a Christian-based country, it is not surprising that students demand that the next generation of Ukrainian pupils learn not only the Christian faith, but also Christian behavior and virtues, including truthfulness, honesty, justice and moral principles in general $(4,2)$. Respondents perceived that it is a necessary basis on which other values can be built, such as self-awareness, the ability to assert oneself, lifelong learning.

\begin{tabular}{|l|l|}
\hline $\begin{array}{l}\text { 10. Should the teacher try to influence the values and attitudes of pupils he/she } \\
\text { teaches? }\end{array}$ & \\
\hline Moral values (respect for truth, justice, man ...) & 4,01 \\
\hline $\begin{array}{l}\text { Values of civic life (respecting one's homeland, showing respect for law and law, civil } \\
\text { liberties ...) }\end{array}$ & 3,8 \\
\hline $\begin{array}{l}\text { Values of individual and social life (self-esteem, responsibility, cooperation, respect } \\
\text { for oneself and others..) }\end{array}$ & 4,06 \\
\hline $\begin{array}{l}\text { Values associated with education (responsibility for own education, for school } \\
\text { results...) }\end{array}$ & 3,91 \\
\hline
\end{tabular}

In the case of this item, the respondents are strongly inclined to agree with all the above statements, all of which have similarly high scores. The respondents see the highest position in terms of very important values not only in the teacher's influence on pupils in individual and social life (4.06), but also in the field of ethics and moral values (4.01). Respondents agree 
with the need for an adequate effect of the teacher on the entrusted pupils. The teacher should form the desired values of self-esteem, responsibility, respect for the truth, for the person, not only in a verbal form, but above all he needs to be a personal example. According to the respondents, the profession of teacher is associated with a great responsibility for education of the new generation. The statement corresponds with the statement of the respondents concerning the motivation to study (Graph 2), in which the motivation for the teaching profession as a significant mission significantly prevails.

\section{Conclusion}

In the eyes of students, the preparation of future teachers is focused primarily on themselves and their professional preparation. Pregraduate preparation includes all components of study necessary for adequate education of the future teacher and all of them bring great benefit to respondents. The most intense influence is perceived from practically oriented disciplines and practice, which allow students to penetrate to the essence of teaching probably the most. Especially the direct contact of students with their teachers during their studies and with their pupils within pedagogical practices most strongly forms their values and attitudes.

It can be stated that undergraduate study forms the values and attitudes of future teachers, because through the individual components of the study they acquire both the necessary knowledge and the ability to understand the difficulty and usefulness of profession of teaching. They help to form knowledge in the chosen specialization, change the initial vision of pedagogical activities of students, form their professional beliefs (Ševčíková, 2020) and develop their worldview. It often forms a completely new view of life and makes it possible to find starting points in various pedagogical situations. Students gain a closer relationship with teaching and the love for pupils deepens thanks to competencies, how to work with pupils, how to communicate with them and to lead them properly. The motivation to study the majority of respondents and their independent thinking about the deeper meaning of the profession of teaching also significantly contributed to this professional formation during their studies. Many desire to be role models for their pupils and thanks to their own role models - teachers who have been a real example, students want to become even better.

\section{Acknowledgement}

This paper has been funded by IGA project of Palacký University Olomouc:

Pupils with different mother tongue and the influence of school and family on their perception of value of education.

IGA_PdF_2020_026

\section{References}

[1] Blížkovský, B. et al. (2000). Středoevropský učitel na prahu učící se společnosti 21. Století. Brno: Konvoj.

[2] Gavora, P. (2010). Úvod do pedagogického výzkumu. Brno: Paido.

[3] Helus, Z. (2004). Dítě v osobnostním pojetí. Praha: Portál.

[4] Chráska, M. (2016). Metody pedagogického výzkumu. Praha: Grada.

[5] Kobzová, P. (2018). Hodnoty v dokumentech ukrajinského školství. In Vyhnálková, P., Plischke, J. (eds). Interkulturní perspektivy studentů doktorských programů a jejich 
př́prava se zaměřením na mezioborovou pestrost. (1st ed., pp. 81-88). Olomouc: Univerzita Palackého v Olomouci.

[6] Kocan, Ihor Jaroslavovič. (2013). Profesijna pidhotovka sučasnoho včitelja: problemy i orientyry/Jevropejski pedahohični studii/. Asociacija rektoriv pedahohičnich universitetiv Jevropy, No. 3-4/2013, pp. 186-196, Retrieved from URL: http://enpuir.npu.edu.ua/bitstream/123456789/11514/1/\%d0\%9aotsan.pdf

[7] Kratochvílová, J. (2007). Nárys proměn pedagogických disciplín v oboru učitelství 1. stupně ZŠ na PdF MU. In Kratochvílová, J., Horká, H. (eds.) Proměny učitelského vzdělávání v kontextu reformy základního školství. Brno: Pedagogické fakultě MU.

[8] Lukášová, H. (2015). Učitelské sebepojetí a jeho zkoumání. Zlín: Univerzita Tomáše Bati ve Zlíně.

[9] Mikešová, J. (2005). Změny v pregraduální přípravě učitelů primárního vzdělávání v návaznosti na evropskou dimenzi. In Jandová R. (Ed.). Př́íprava učitelů a aktuální proměny v základním vzdělávání. (1st ed., pp. 98-101) České Budějovice: Jihočeská univerzita.

[10] Spilková V. (2015). Pojetí kvality učitele v mezinárodní perspektivě. In Greger, D.,(Ed.) Srovnávací pedagogika: Proměny a výzvy. (1st ed., pp. 163-178). Praha: Univerzita Karlova v Praze.

[11] Spilková, V. (2007) Proměny vzdělávání učitelů v kontextu kurikulární reformy. In Kratochvílová, J., Horká, H. (Eds.) Proměny učitelského vzdělávání v kontextu reformy základního školství. Brno: Pedagogické fakultě MU.

[12] Ševčíková, J. (2020). Vybrané aspekty formování profesního přesvědčení začínajících učitelů. In: Rajský, A. (Ed). JUVENILIA PAEDAGOGICA 2020. Trnava: Trnavská univerzita, PdF.

[13] Volynec, Katerina Ivanivna (2013). Profesijna pidhotovka majbutňoho včitelja počatkovoji školy v umovach neperervnosti pedahohičnoji osvity v universiteti. In Vašenko, O.M.(Ed). Profesijna pidhotovka majbutňoho včitelja počatkovoji školy: teorija i praktika. (1st ed., 5-20). Kyiv: Kyivskyj Universitet Imeni Borisa Hrinčenka. Retrieved from URL: http://elibrary.kubg.edu.ua/id/eprint/5150/

[14] Zákon No. 2145-VIII, Zákon Ukrajiny o vzdělávání. (2017). Retrieved from URL: https://zakon.rada.gov.ua/laws/show/2145-19\#Text 